\title{
Provenance and deposition of glacial Lake Missoula lacustrine and flood sediments determined from rock magnetic properties
}

\author{
Michelle Andrée Hanson ${ }^{\mathrm{a}, *}$, Randolph Jonathan Enkin ${ }^{\mathrm{b}}$, René William Barendregt ${ }^{\mathrm{c}}$, John Joseph Clague ${ }^{\mathrm{d}}$ \\ a Saskatchewan Geological Survey, 200-2101 Scarth Street, Regina, Saskatchewan S4P 2H9, Canada \\ b Geological Survey of Canada, P.O. Box 6000, Sidney, British Columbia V8L 4B2, Canada \\ c University of Lethbridge, 4401 University Drive, Lethbridge, Alberta T1K 3 M4, Canada \\ d Department of Earth Sciences, Simon Fraser University, 8888 University Drive, Burnaby, British Columbia V5A 1S6, Canada
}

\section{A R T I C L E I N F O}

\section{Article history:}

Received 8 April 2014

Available online $\mathrm{xxxx}$

\section{Keywords:}

Glacial Lake Missoula

Rock magnetic properties

Glacial Lake Columbia

Glacial outburst floods

Magnetic hysteresis

Thermomagnetic susceptibility

\begin{abstract}
A B S T R A C T
Repeated outburst flooding from glacial Lake Missoula, Montana, affected large areas of Washington during Marine Oxygen Isotope Stage 2 (29-14 ka). We present the first high-resolution rock magnetic results from two sites that are critical to interpreting these outburst floods and that provide evidence of sediment provenance: glacial Lake Missoula, the source of the floods; and glacial Lake Columbia, where floodwaters interrupted sedimentation. Magnetic carriers in glacial Lake Missoula varves are dominated by hematite, whereas those in outburst flood sediments and glacial Lake Columbia sediments are mainly magnetite and titano-magnetite. Stratigraphic variation of magnetic parameters is consistent with changes in lithology. Importantly, magnetic properties highlight depositional processes in the flood sediments that are not evident in the field. In glacial Lake Columbia, hematite is present in fine silt and clay deposited near the end of each flood as fine sediment settled out of the water column. This signal is only present at the end of the floods because the hematite is concentrated in the finer-grained sediment transported from the floor of glacial Lake Missoula, the only possible source of hematite, $\sim 240 \mathrm{~km}$ away.
\end{abstract} (c) 2014 University of Washington. Published by Elsevier Inc. All rights reserved.

\section{Introduction}

During the last, or Fraser glaciation (Marine Oxygen Isotope Stage 2 , 29-14 ka), the Purcell Trench lobe of the Cordilleran ice sheet advanced south into Idaho and dammed Clark Fork River, impounding glacial Lake Missoula in the intermontane basins of western Montana (Fig. 1; Pardee, 1910, 1942). At approximately the same time, the Okanogan lobe, farther west, dammed Columbia River, creating glacial Lake Columbia in northeast Washington (Fig. 1; Bretz, 1932; Waitt and Thorson, 1983; Atwater, 1984, 1986). For several thousand years, between approximately 17.2 and $11.6{ }^{14} \mathrm{C}$ ka BP (Clague et al., 1980; Kuehn et al., 2009), glacial Lake Missoula repeatedly filled and emptied catastrophically (Chambers, 1971; Baker, 1973; Chambers, 1984; Waitt, 1984, 1985). Floodwaters entered glacial Lake Columbia, where deposits of approximately 89 separate floods are interbedded with glacial Lake Columbia sediments (Atwater, 1986). Floodwaters also spilled across basalts of the Columbia Plateau, creating the distinctive topography of the Channeled Scablands of eastern Washington and depositing giant flood bars and current dunes, as well as fine-grained, rhythmically bedded, slackwater sediments in central Washington (Fig. 1; Bretz, 1925, 1928; Bretz et al., 1956; Baker, 1973; Bjornstad, 1980; Waitt,

\footnotetext{
* Corresponding author.

E-mail address: Michelle.Hanson@gov.sk.ca (M.A. Hanson).
}

1980; Bunker, 1982; Waitt, 1985; Waitt et al., 2009). The floods continued down Columbia Valley and backed up into Willamette Valley in Oregon, where they deposited a sequence of fine-grained slackwater sediments (Fig. 1; Allison, 1978; Waitt, 1980, 1985; O'Connor et al., 2001). Each time, all of the floodwaters reached the Pacific Ocean at the mouth of Columbia River within a few weeks (Baker, 1973; Craig, 1987; O'Connor and Baker, 1992; Denlinger and O'Connell, 2010).

The number of times that glacial Lake Missoula drained catastrophically during the last glaciation was a source of controversy for decades. Estimates of the number of floods range from one to nearly 100 . Debate focussed largely on the rhythmically bedded slackwater deposits in the Walla Walla and Yakima valleys of Washington (Fig. 1), where individual beds were attributed to either single floods (Waitt, 1980, 1985) or to hydraulic surging during a single or a few floods (Bretz et al., 1956; Bretz, 1969; Baker, 1973, 1978; Carson et al., 1978; Patton et al., 1979; Bjornstad, 1980; Bunker, 1982; Baker and Bunker, 1985; Smith, 1993; Shaw et al., 1999). Work on the paleomagnetic secular variation record of the slackwater sediments and flood sediments in glacial Lake Columbia (Lovett, 1984; Kietzman, 1985; Steele, 1991; Clague et al., 2003) has shown that the sequence of rhythmic beds must record dozens of individual floods separated by decades. Interflood varve counts in glacial lake Columbia attest to similar timing between flood events (Atwater, 1986). There is still debate, however, as to whether all of these floods were sourced from glacial Lake Missoula or whether there was another source, such as glacial Lake Columbia or a water body beneath the 

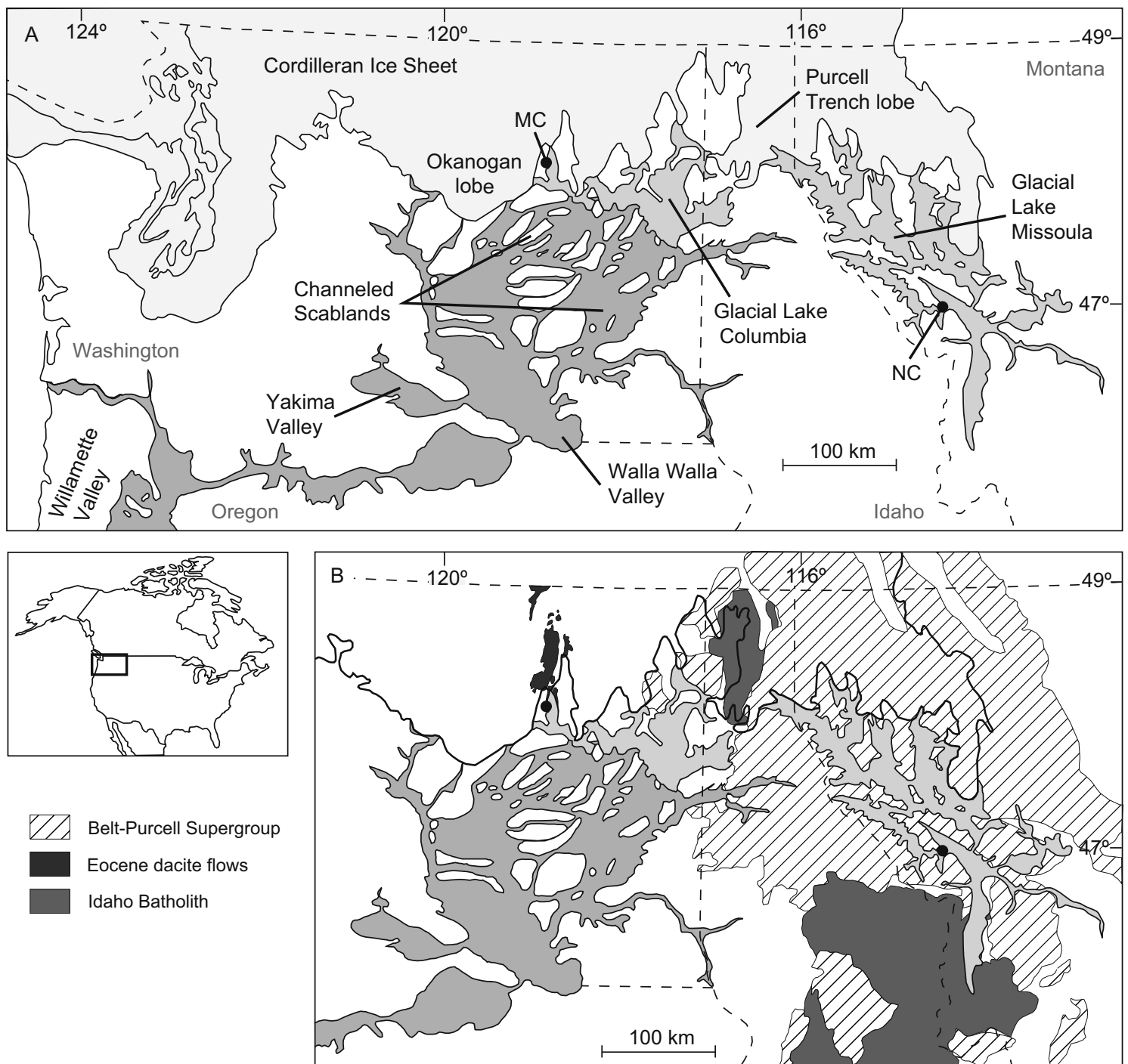

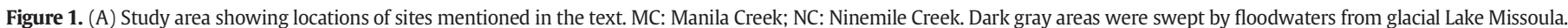

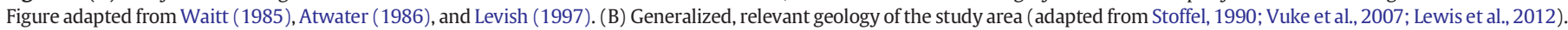

Cordilleran ice sheet (Bretz et al., 1956; Bretz, 1969; Baker and Bunker, 1985; Shaw et al., 1999; Gaylord et al., 2005, 2007; Lesemann and Brennand, 2009).

Many researchers have conducted sedimentological studies on glacial Lake Missoula lacustrine sediments and on the flood sediments and landforms produced by outburst floods from the lake (Chambers, 1971; Baker, 1973; Bjornstad, 1980; Waitt, 1980; Bunker, 1982; Chambers, 1984; Waitt, 1984, 1985; Smith, 1993; Levish, 1997; Smith, 2006; Hanson et al., 2012). This study is the first to examine these sediments from a rock magnetic perspective. Magnetic properties characterize the mineralogy, concentration, and magnetic domain state of the iron oxide and sulfide minerals found in the sediments, providing a sensitive tool for investigating sediment transport and deposition, as well as provenance. In this paper, we present a rock magnetic record of lacustrine sediments deposited in glacial Lake Missoula, and interbedded flood and lacustrine sediments deposited in glacial Lake Columbia. The purpose of this study is two-fold: first to determine the magnetic characteristics of the sediments and relate them to different sedimentary environments and sedimentary processes; and second to determine different potential provenances of sediment in glacial Lake Columbia in order to resolve the controversy surrounding the source of flood deposits in Washington and Oregon.

\section{Study areas}

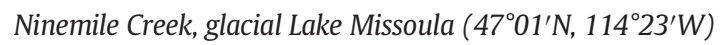

The Ninemile Creek section (Fig. 1), a roadcut along Interstate Highway 90 in western Montana that was originally described by Chambers $(1971,1984)$, is the unofficial type section for fine-grained glacial Lake Missoula lacustrine sediments. Thirty-four units, ${ }^{1}$ ranging in thickness from 0.22 to $3.30 \mathrm{~m}$ and commonly thinning up-section, are exposed at this site. Each unit records a separate glacial Lake Missoula ponding event and has two sub-units (Fig. 2A). The lower sub-unit is characterized by a sharp, erosional lower contact and rippled and laminated fine sand and silt (Fig. 2A). This sub-unit was likely deposited by turbidity currents in relatively shallow water as glacial Lake Missoula began to fill (Chambers, 1971, 1984; Hanson et al., 2012). It grades upward into a sub-unit of silt and clay varves, which are annual sediment layers

\footnotetext{
${ }^{1}$ In this paper, we define "unit" as: (1) an ensemble of lithofacies recording a single lake phase from filling through maximum stage to drainage (e.g., glacial Lake Missoula); or (2) an ensemble of lithofacies recording a single glacial Lake Missoula flood event, including flood-deposited sediments and interbedded glaciolacustrine sediments deposited between successive floods (e.g., glacial Lake Columbia).
} 

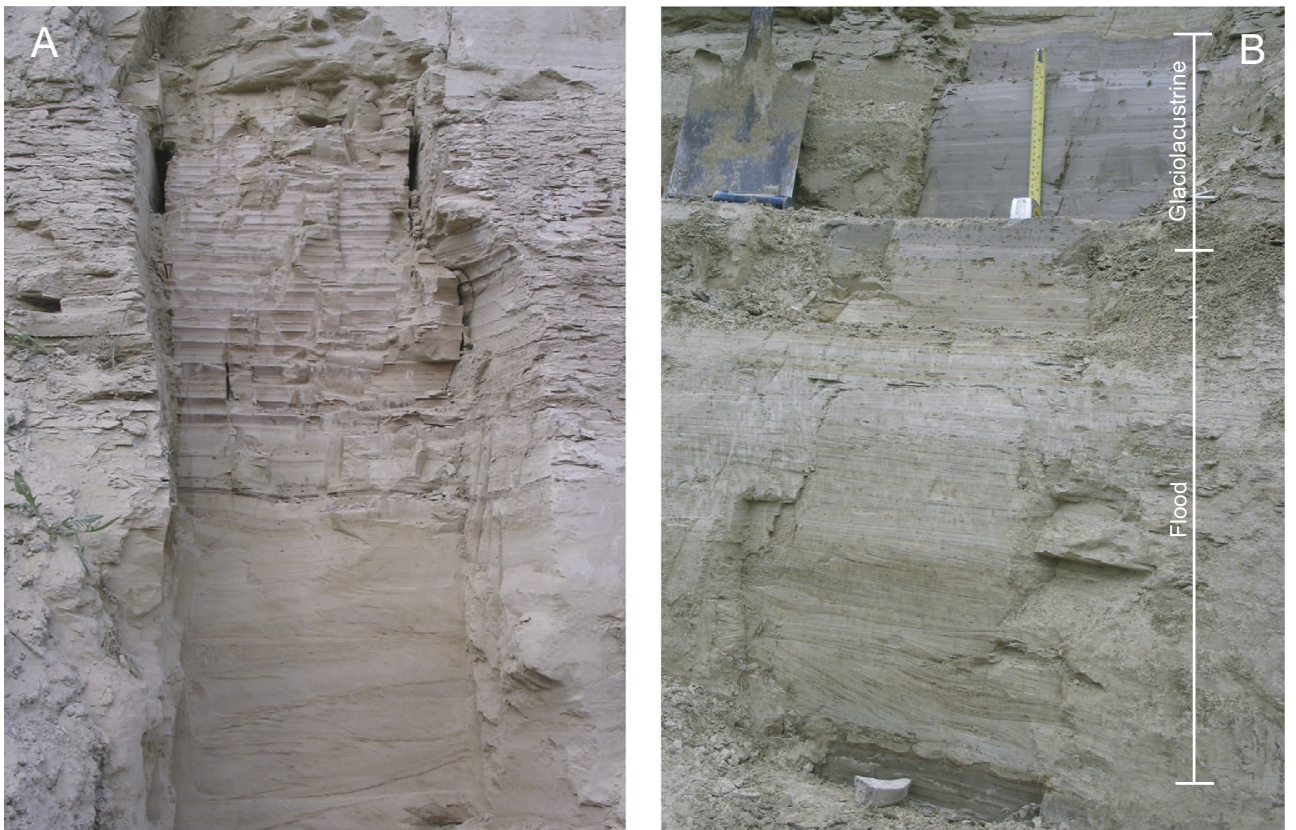

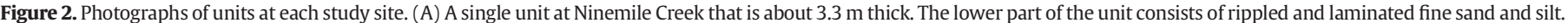

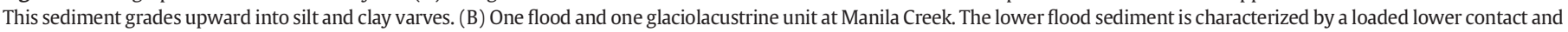
planar and inclined silt and clay laminations. The flood sediments grade up into glaciolacustrine, laminated clayey silt. The tape is about $30 \mathrm{~cm}$ long.

comprising a bed of relatively coarse (silt) sediment deposited by summer currents overlain by a bed of finer sediment (clay) that settles out of suspension during winter (Fig. 2A). Varves range from 0.3 to $20 \mathrm{~cm}$ thick, and the thickness of individual varves commonly decreases upward within the sub-unit, reflecting a progressive increase in the depth of the lake. The number of observed varves per unit ranges from 2 to 44 and averages 19 . The total number of varves counted at Ninemile Creek is 583. Taking into consideration probable erosion of sediment during lake draining events and unrecorded lake refilling time, the entire exposure may record approximately 1500 yr (Hanson et al., 2012).

\section{Manila Creek, glacial Lake Columbia $\left(48^{\circ} 00^{\prime} N, 118^{\circ} 42^{\prime} W\right)$}

Atwater $(1986,1987)$ originally described glacial Lake Columbia sediments at Manila Creek (Fig. 1). At this site, glacial Lake Columbia sediments alternate with beds deposited by glacial Lake Missoula floodwaters (Fig. 2B). Up to 89 flood cycles have been reported here (Atwater, 1986, 1987), 46 of which were accessible for this study. Flood beds are 0.05 to $0.91 \mathrm{~m}$ thick and commonly thin up-section. They are characterized by erosional or loaded lower contacts; planar, inclined, or convoluted laminations of fine sand, silt, and clay; rippled fine sand and silt; and soft-sediment deformation structures indicative of rapid deposition (Fig. 2B). Flood units grade up into glacial Lake Columbia bedded and laminated very fine silt and clay (Fig. 2B). The glaciolacustrine units range from 0.04 to $1.69 \mathrm{~m}$ thick and, like the flood units, thin up-section. We were unable to consistently identify varves, but the 46 units record between 700 and $2600 \mathrm{yr}$ (Atwater, 1986; Hanson, 2013).

\section{Methods}

Sampling

We collected 106 samples for detailed rock magnetic analysis - 44 samples from over three successive units at Ninemile Creek, 49 samples through just over two units in the lower part of the Manila Creek exposure, and 13 samples for thermomagnetic susceptibility measurements. We collected samples at 3-4 cm intervals. Between 9 and 16 plastic cylinders ( $2.5 \mathrm{~cm}$ diameter, $2.2 \mathrm{~cm}$ length) were inserted horizontally into vertically cleaned faces of each flood or glaciolacustrine unit, oriented using a Brunton compass, and removed for paleomagnetic analysis. We collected 288 additional samples at Manila Creek through the lower 25 units for magnetic remanence and magnetic susceptibility measurements only.

\section{Magnetic remanence and susceptibility}

We made all magnetic measurements at the Paleomagnetism and Petrophysics Laboratory at the Geological Survey of Canada. Paleomagnetic measurements were made on an AGICO JR5A spinner magnetometer. We measured loexposurew-field volume magnetic susceptibility $(K)$ of all samples with a Sapphire SI2B Susceptibility Meter.

\section{Thermomagnetic susceptibility}

The temperature dependence of magnetic susceptibility $\left(\chi_{0}-T\right)$ indicates magnetic and mineralogical changes during heating and thus can be used to identify magnetic minerals (Dunlop and Özdemir, 1997; Hrouda, 2003). We measured temperature dependence of lowfield mass-specific magnetic susceptibility $\left(\chi_{0}\right)$ of 14 samples using a Bartington MS2WFP - six from Ninemile Creek and eight from Manila Creek (Table 1). Measurements were taken continuously as samples were heated from approximately room temperature to $700^{\circ} \mathrm{C}$ and then cooled to $100^{\circ} \mathrm{C}$. We performed each run over a period of approximately $1 \mathrm{~h}$ on samples weighing between 1.26 and $2.59 \mathrm{~g}$. The average heating and cooling rates were, respectively, approximately $15^{\circ} \mathrm{C}$ per minute and $40^{\circ} \mathrm{C}$ per minute. We determined the Curie temperature $\left(T_{C}\right)$, which is the temperature at which a ferromagnetic material loses its ferromagnetic properties and becomes paramagnetic, by extrapolating the tangent line at the inflection point of the thermomagnetic curve to the $\mathrm{x}$-axis (Lattard et al., 2006).

\section{Magnetic hysteresis-loop parameters}

We measured magnetic hysteresis-loop parameters of 93 samples at room temperature using a J-meter coercivity spectrometer (Enkin et al., 
Table 1

Curie temperatures and inferred magnetic mineralogy of samples analyzed for thermomagnetic susceptibility.

\begin{tabular}{|c|c|c|c|c|c|c|}
\hline Sample code & $T_{\mathrm{C}}\left({ }^{\circ} \mathrm{C}\right)$ & Dominant magnetic mineral & Site $^{a}$ & Symbol $^{\text {b }}$ & $\mathrm{D}_{50}(\mu \mathrm{m})$ & Depositional environment \\
\hline LKG134 & 555 & Titano-magnetite & $\mathrm{NC}$ & $\square$ & 14.0 & Initial lake filling \\
\hline LKG139A & 660 & Hematite & $\mathrm{NC}$ & $\diamond$ & 2.5 & Varves \\
\hline LKG139B & 657 & Hematite & $\mathrm{NC}$ & $\diamond$ & 2.2 & Varves \\
\hline LKG140 & 662 & Hematite & $\mathrm{NC}$ & $\diamond$ & 2.4 & Varves \\
\hline LKG141 & 565 & Titano-magnetite & $\mathrm{NC}$ & $\square$ & 16.6 & Initial lake filling \\
\hline LKG145 & 660 & Hematite & $\mathrm{NC}$ & $\diamond$ & 2.1 & varves \\
\hline LKF077 & 561 & Titano-magnetite & $\mathrm{MC}$ & $\nabla$ & 30.9 & Flood \\
\hline LKF085 & 598 & Magnetite & $\mathrm{MC}$ & $\Delta$ & 3.9 & Glaciolacustrine \\
\hline LKF090 & 558 & Titano-magnetite & $\mathrm{MC}$ & $\nabla$ & 10.0 & Flood \\
\hline МАH048 & 640 & Hematite & MC & $\Delta$ & 2.4 & Top of glaciolacustrine \\
\hline WMHO03 & 551 & Titano-magnetite & $\mathrm{MC}$ & $\nabla$ & 12.4 & Flood \\
\hline WMH007 & 600 & Magnetite & $\mathrm{MC}$ & $\Delta$ & 3.9 & Glaciolacustrine \\
\hline WMH010 & 557 & Titano-magnetite & $\mathrm{MC}$ & $\nabla$ & 22.4 & Flood \\
\hline WMH015 & 603 & Magnetite & MC & $\Delta$ & 5.5 & Glaciolacustrine \\
\hline
\end{tabular}

${ }^{\mathrm{a}} \mathrm{MC}=$ Manila Creek; NC = Ninemile Creek.

b Symbols relate to Figures 4-7.

2007) with a maximum applied field of $500 \mathrm{mT}$. We obtained saturation magnetization $\left(J_{S}\right)$, saturation remanence $\left(J_{R S}\right)$, coercive force $\left(H_{C}\right)$, and coercivity of remanence $\left(H_{\mathrm{CR}}\right)$ after subtracting the paramagnetic susceptibility $\left(K_{\mathrm{P}}\right)$ contribution identified from the slope at fields $>400 \mathrm{mT}$.

\section{Grain-size analysis}

We performed grain-size analysis on all samples for which hysteresis parameters were determined using a Malvern Mastersizer 2000 laser granulometer, which can measure particles ranging from 0.02 to
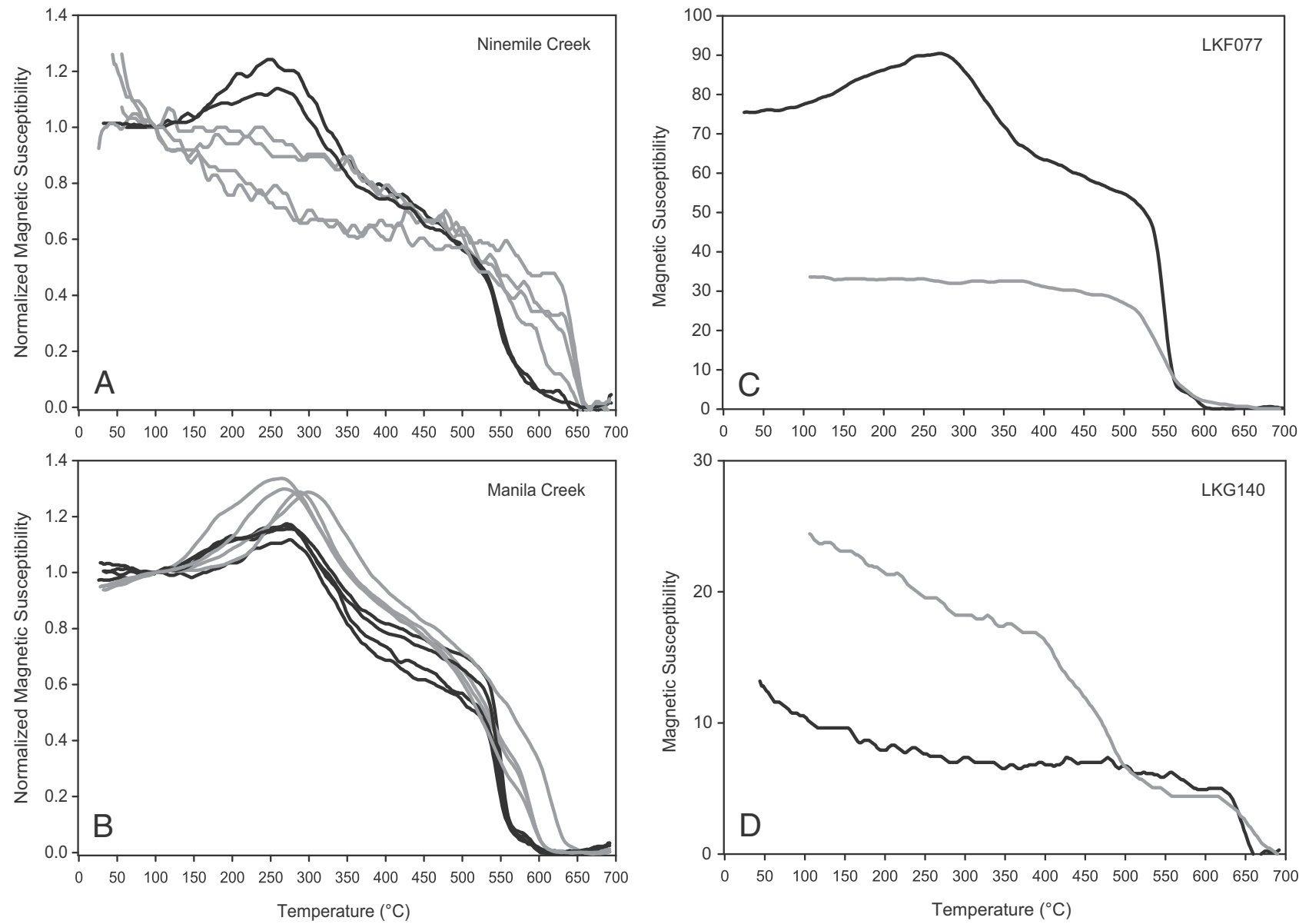

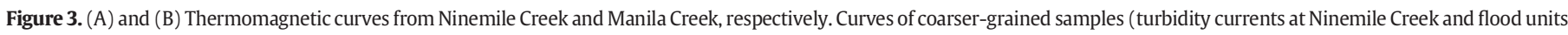

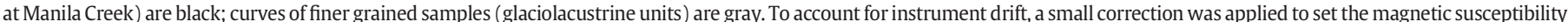

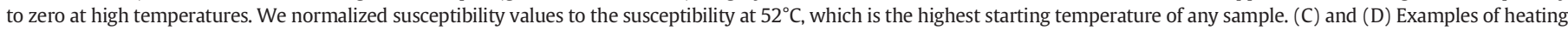

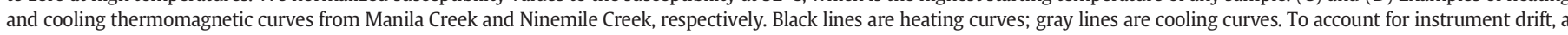
small correction was applied to set the magnetic susceptibility to zero at high temperatures. 


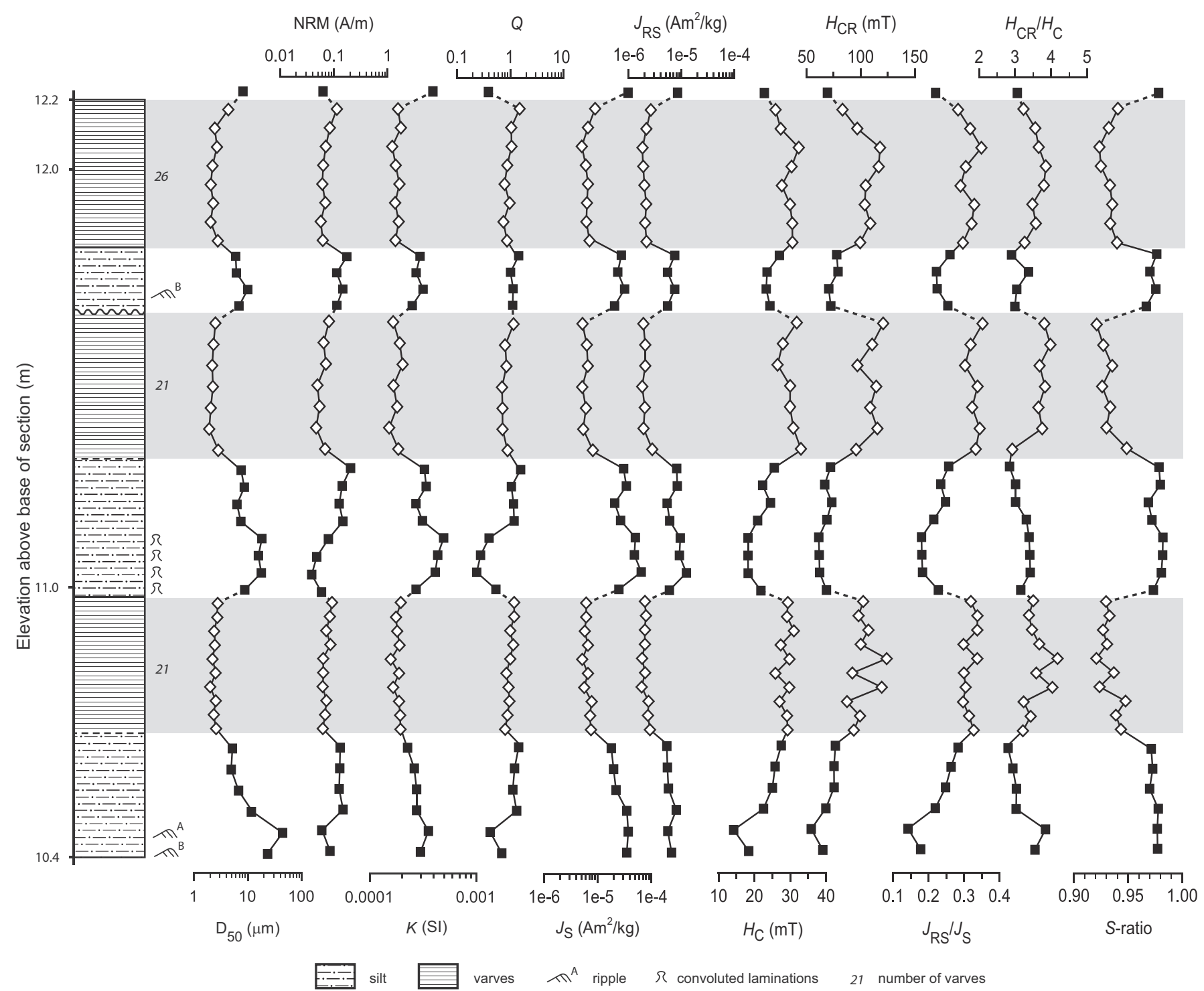

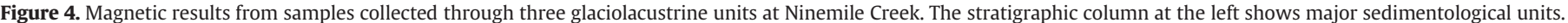

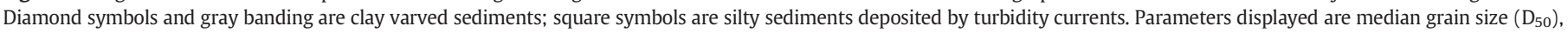

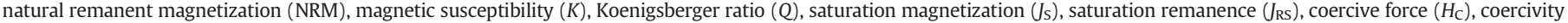
of remanence $\left(H_{\mathrm{CR}}\right)$, and the $S$-ratio.

$2000 \mu \mathrm{m}$. Our standard operating protocol is based on the work of Sperazza et al. (2004) and involved multiple trial runs of both a fine silt sample $\left(D_{50}=9.7 \mu \mathrm{m}\right)$ and a clay-sized sample $\left(D_{50}=2.9 \mu \mathrm{m}\right)$ from Ninemile Creek. We obtained subsamples of less than $2 \mathrm{~g}$ of sediment from the paleomagnetic cylinders for grain-size analysis. We soaked subsamples in $10 \mathrm{~mL}$ of a $0.55 \%$ sodium hexametaphosphate solution for approximately $16 \mathrm{~h}$ to disperse the grains. The subsamples were then mechanically stirred and sediment was drawn off with a pipette for analysis. The Udden-Wentworth scale (Wentworth, 1922) was used for textural classification. We note that laser granulometers tend to underestimate the clay fraction of samples because of the platy shape of clay minerals (Hao et al., 2008).

\section{Results}

The Koenigsberger ratio $(Q)$ is the ratio of natural remanent magnetization to induced magnetization and is used to indicate the efficiency of magnetic acquisition. In sediments, a value above one indicates that the magnetic grains are individually stable (single-domain) and highly aligned, indicating that they were deposited in a low-energy environment (Carter-Stiglitz et al., 2006). The Koenigsberger ratios for our samples are high for sediments; $91 \%$ of the samples have a $Q$ value of greater than one. The Koenigsberger ratio and all other measured values discussed are plotted in Figures $3-6^{2}$ and are listed in Table 1 and the Supplementary Table.

\section{Thermomagnetic susceptibility}

Thermomagnetic susceptibility heating curves are displayed in Figures $3 \mathrm{~A}$ and $\mathrm{B}$, grouped according to site. Table 1 shows the $T_{C}$ of samples and inferred magnetic mineralogy. The thermomagnetic heating curves are of two types. At both sites, the heating curves that indicate the presence of magnetite or titano-magnetite have similar shapes.

2 Note that sample MAH066, at the top of the first complete glaciolacustrine unit at Manila Creek (highlighted in gray in Fig. 5), is an anomalous sample that, in most cases (e.g., $K$ and some hysteresis parameters) does not follow the trend of the other samples. An explanation for this anomaly is beyond the scope of this paper, thus this sample is plotted in Fig. 5 but is excluded when discussing parameter trends. 


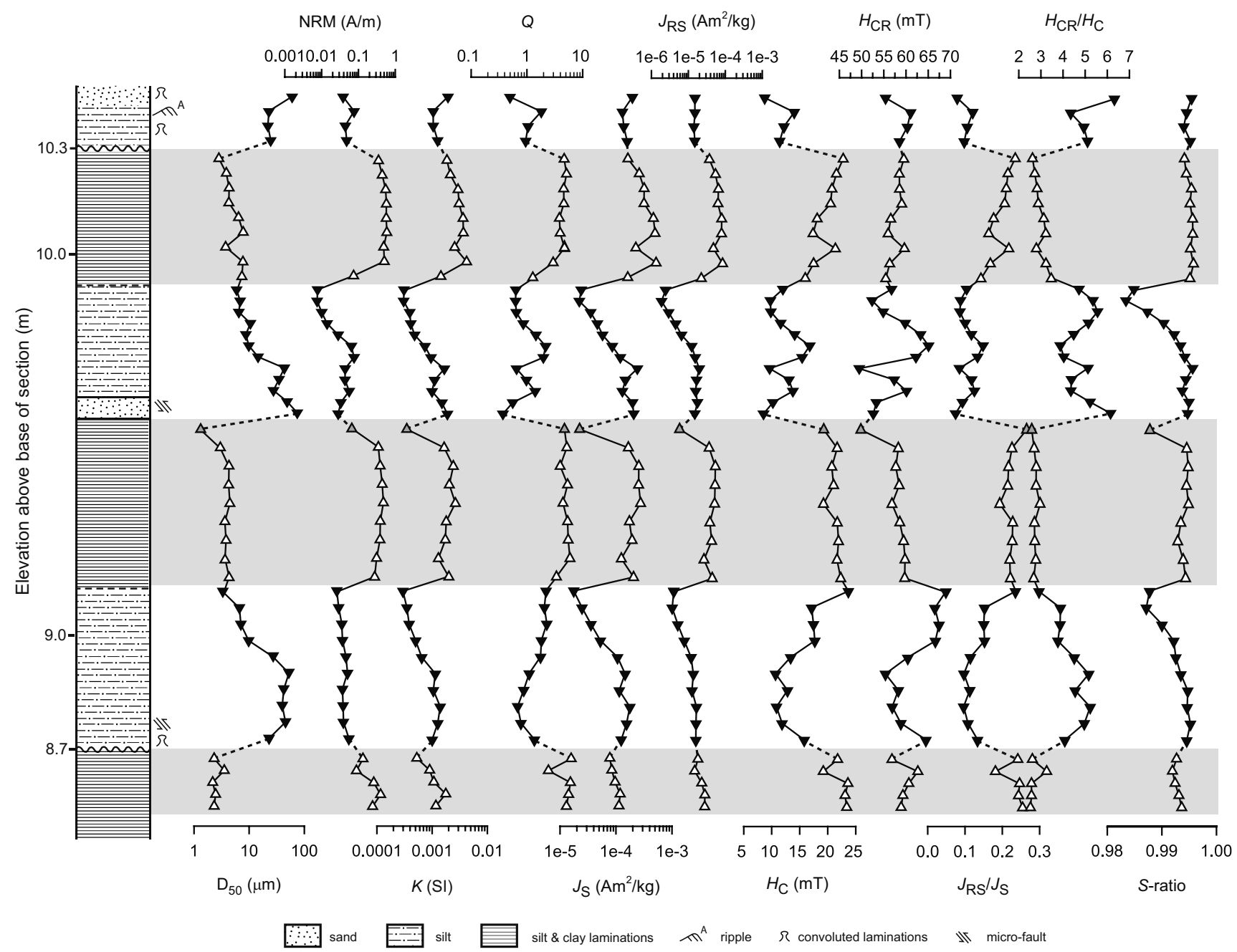

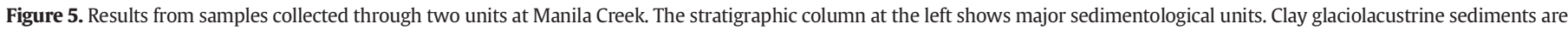

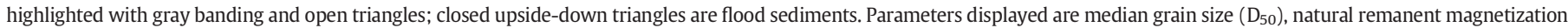

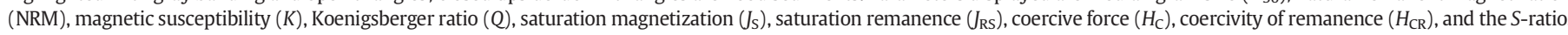
One sample, highlighted in gray, is anomalous; see footnote 2 for details.

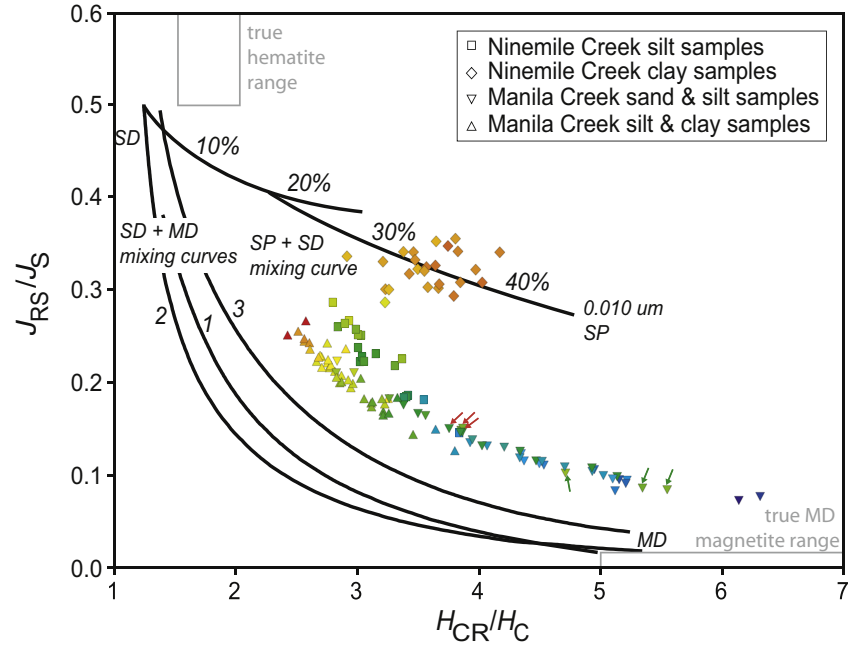

Figure 6. Hysteresis ratios for the two datasets shown on a Day plot. SD + MD and SP + SD mixing lines are from Dunlop (2002a). MD: multi-domain; SD: single domain; SP: superparamagnetic. The colors show a change in median grain size from $1.2 \mu \mathrm{m}$ (red) to $78 \mu \mathrm{m}$ (dark blue). The arrows indicate the top three samples in the two Manila Creek flood units (red = lower unit; green = upper unit). (For interpretation of the references to color in this figure, the reader is referred to the web version of this article.)
These curves are characterized by a steady increase of $~ 20 \%$ in susceptibility up to between $250^{\circ} \mathrm{C}$ and $350^{\circ} \mathrm{C}$, followed by a gradual, and then more sudden, decrease toward the Curie temperature between $550^{\circ} \mathrm{C}$ and $600^{\circ} \mathrm{C}$. The peak between $250^{\circ} \mathrm{C}$ and $350^{\circ} \mathrm{C}$ is commonly seen in samples that contain organic matter and is thought to indicate conversion of ferrimagnetic maghemite to weakly magnetic hematite (Stacey and Banerjee, 1974). However, there has been no pedogenesis or significant weathering at the sample sites, thus we would not expect maghemite in these samples. The second type of heating curve displays a generally steady decrease in susceptibility toward the Curie temperature well above $600^{\circ} \mathrm{C}$ and is characteristic of hematitebearing samples. The thermomagnetic curves from Ninemile Creek (Fig. 3A) are noisier than the Manila Creek curves (Fig. 3B) because they have lower magnetic susceptibility, nearer the sensitivity limit of the equipment.

Cooling curves also are of two forms, examples of which are shown in Figures $3 \mathrm{C}$ and D. Cooling curves derived from samples dominated by magnetite and titano-magnetite (Fig. 3C) have distinctly lower susceptibilities than the associated heating curves, due to oxidation of magnetite to hematite. The cooling curves of the hematite-bearing samples (Fig. 3D) have higher susceptibilities than the heating curves, indicating that some hematite was reduced to magnetite during the heating process (Hrouda et al., 2002, 2003; Hrouda, 2003). 


\section{Room-temperature magnetic susceptibility}

Volumetric magnetic susceptibility $(K)$ depends on the concentration, mineralogy, and grain size of the magnetic fraction of the sample. Susceptibility is used as a measure of the concentration of ferrimagnetic minerals such as magnetite and titano-magnetite (Stacey and Banerjee, 1974; Opdyke and Channell, 1996). The contributions of diamagnetic, antiferromagnetic, and paramagnetic minerals to susceptibility are negligible because their susceptibilities are 10-100 times lower than those of magnetite and titanium-magnetite (Blanchet et al., 2007). If, however, the concentration of ferrimagnetic material is low, $K$ depends on antiferromagnetic material such as hematite (Opdyke and Channell, 1996).

The following observations are of note: (1) at Ninemile Creek (Fig. 4), higher susceptibility values in the silts than the clay varves are consistent with $\chi_{0}-T$ measurements, which indicate the presence of titano-magnetite in the silts and hematite in the clays; (2) at Manila Creek (Fig. 5), susceptibility decreases toward the top of each flood unit, which is consistent with the upward decrease in grain size as dense magnetite grains are preferentially transported with larger grains of common minerals. It is striking, however, that $K$ increases abruptly from the top of each flood unit into the base of the overlying finer glaciolacustrine unit considering that the dominant magnetic mineral in both units is either titano-magnetite or magnetite and that grain size decreases upward. Additionally, $K$ does not change significantly across the erosional contact at the base of the flood unit where grain size markedly increases.

\section{Hysteresis properties}

Hysteresis measurements provide information about the type, concentration, and domain state of magnetic minerals. We note that the samples were subjected to a maximum field of $500 \mathrm{mT}$, and so values of saturation magnetization $\left(J_{S}\right)$, saturation remanence $\left(J_{R S}\right)$, coercive force $\left(H_{\mathrm{C}}\right)$, and coercivity of remanence $\left(H_{\mathrm{CR}}\right)$ will be underestimated for samples dominated by hematite (i.e., varved clay sediment at Ninemile Creek), which requires a field of up to $3 \mathrm{~T}$ to saturate.

Saturation magnetization $\left(J_{S}\right)$ and saturation remanence $\left(J_{R S}\right)$ depend primarily on magnetic mineral content, but the ratio $J_{\mathrm{RS}} / J_{\mathrm{S}}$ is mostly dependent on domain state. Both $J_{S}$ and $J_{\mathrm{RS}}$ strongly or very strongly correlate to $K$ if magnetite or titano-magnetite is the dominant magnetic mineral. At Manila Creek, $J_{S}$ and $J_{R S}$ follow the same unexpected trend of $K$ from the flood sediments to the glaciolacustrine sediments.

Coercive force $\left(H_{\mathrm{C}}\right)$ and coercivity of remanence $\left(H_{\mathrm{CR}}\right)$ are key parameters in discriminating ferromagnetic and antiferromagnetic minerals. They increase in the presence of higher-coercivity, more stable minerals such as hematite (e.g., clay varves at Ninemile Creek, Fig. 4; Maher and Thompson, 1999; Blanchet et al., 2007). Coercivity of remanence is also a measure of domain state for a given magnetic mineral, with higher values indicating smaller, more stable magnetic grains (Maher and Thompson, 1999; Blanchet et al., 2007). At Manila Creek (Fig. 5), the range of values within the flood units is considerable; in the first flood, higher coercivity minerals are common toward the end; and in the second flood, they are more common in the middle. Overall, $H_{\mathrm{C}}$ and $H_{\mathrm{CR}}$ are negatively correlated to grain size.

Figure 6 is a Day plot showing the ratios $J_{\mathrm{RS}} / J_{\mathrm{S}}$ and $H_{\mathrm{CR}} / H_{\mathrm{C}}$, which are used to determine domain states or magnetic grain sizes (Day et al., 1977). The Day plot was designed for use only for samples that contain magnetite, but we plot all of our samples in Figure 6. All samples are above the theoretical mixing curves for single domain (SD) and multi-domain (MD) grains (Fig. 6; Dunlop, 2002a). Most samples plot near the pseudo-single domain (PSD) range, well below the superparamagnetic and single domain (SP + SD) mixing curve. The Ninemile Creek varved clay samples cluster around the magnetite
SP + SD mixing curve, but only because the hematite was not saturated and thus the two ratios are anomalous. $H_{\mathrm{C}}$ is low for the hematite samples, resulting in high $H_{\mathrm{CR}} / H_{\mathrm{C}}$ ratios; and the highest coercivity grains are not saturated, leading to low $J_{\mathrm{RS}} / J_{\mathrm{S}}$ values. If hematite were truly saturated, it would plot higher than 0.5 on the y-axis of the Day plot and between 1.5 and 2 on the x-axis (Fig. 6; Dunlop, 2002b). Similarly, the presence of some hematite in the titano-magnetite in the Ninemile Creek silts displaces these samples toward the magnetite SP + SD mixing curves.

\section{S-ratio}

The S-ratio (Stober and Thompson, 1979) provides a measure of the proportion of low-coercivity ferromagnetic grains to high-coercivity grains. Because the maximum field of the coercivity spectrometer is $500 \mathrm{mT}$, the $S$-ratio used here is $\left(J_{\mathrm{RS}} 500 \mathrm{mT}-J_{\mathrm{RS}}{ }^{400 \mathrm{mT}}\right) / J_{\mathrm{RS}} 500 \mathrm{mT}$. This ratio approaches unity as the proportion of low-coercivity magnetic grains, such as magnetite, increases. A lower value indicates the presence of a higher coercivity magnetic mineral, such as hematite, that is not saturated at the lower value $(400 \mathrm{mT})$ but is closer to saturation at the higher value $(500 \mathrm{mT})$. Hematite will not be fully saturated in this experiment, because it requires an applied field of more than $3 \mathrm{~T}$ for complete saturation. Titano-magnetite, on the other hand, is always saturated in fields below $300 \mathrm{mT}$. Thus we use the ratio to distinguish the relative amounts of magnetite and hematite at the different sites. Because the saturation magnetization of hematite is about $1 / 200$ that of magnetite (Dunlop and Özdemir, 1997) and the hematite is not saturated at our maximum applied field, an S-ratio below 0.99 means there is more than twice as much hematite as magnetite in the sample.

$S$-ratios are low, dipping down to 0.90 . Ninemile Creek has the lowest $S$-ratio values (mean $=0.95$ ), indicating the presence of about 10 times greater concentration of hematite than magnetite in the sediment (Fig. 4). More hematite is present in the upper clay sub-units than in the lower silt sub-units, which is consistent with the $\chi_{0}-T$ results. Most S-ratio values at Manila Creek (Fig. 5) are higher than those at Ninemile Creek (mean $=0.99$ ), indicating that a low-coercivity magnetic mineral, such as magnetite or titano-magnetite, is dominant. There is, however, considerable variation within the Manila Creek results. The $S$-ratio values are constant across the erosional boundary at the base of a flood unit, but decrease at the end of a flood unit, a pattern similar to those shown by $\mathrm{NRM}, K, J_{\mathrm{S}}$, and $J_{\mathrm{RS}}$ values. Thus, the proportion of hematite increases toward the end of the floods.

\section{Discussion}

Rock magnetic measurements are easy to obtain, and we show that they can complement detailed sedimentological data, such as grain-size distributions and sedimentary structures. Magnetic methods focus on a small but sensitive sub-population of the sediment load: the iron oxides and sulfides. These minerals provide unique information on sediment provenance and transport mechanisms that are not necessarily discernable from field evidence. Table 2 summarizes the key magnetic properties of each depositional environment that are discussed below.

\section{Magnetic properties and depositional environment}

High Koenigsberger ratios $(Q>1)$ attest to high alignment of stable magnetic grains deposited in relatively low-energy settings. High ratios are characteristic of all Ninemile Creek samples, except those that record the early stage of lake filling when turbidity currents were present and sedimentation was more rapid (Fig. 4). At Manila Creek, the lake sediment samples are almost as well aligned, whereas the flood sediment samples have lower $Q$ values. These lower values are to be 
Table 2

Summary of the key magnetic properties for each depositional environment.

\begin{tabular}{|c|c|c|}
\hline Location & Sedimentary environment & Key magnetic properties \\
\hline \multirow[t]{2}{*}{$\begin{array}{l}\text { Glacial Lake Missoula } \\
\text { (Ninemile Creek) }\end{array}$} & $\square^{\mathrm{a}}$ Initial lake filling - laminated and rippled fine sand and silt & $\begin{array}{l}\text { - Magnetic domain: difficult to determine; trending toward PSD } \\
\text { - } \chi_{0}-T, H_{\mathrm{C}}, H_{\mathrm{CR}} \text {, and } S \text {-ratio: titano-magnetite is the dominant magnetic mineral; } \\
\text { hematite, if present, is masked by the titano-magnetite } \\
\text { - Titano-magnetite comes from the surrounding Belt-Purcell Supergroup or the } \\
\text { Idaho Batholith to the south } \\
\text { - } K \text { decreases up-unit } \\
\text { - Grain size (mean }=11.6 \mu \mathrm{m} \text { ) decreases up-unit }\end{array}$ \\
\hline & $\diamond$ Deepened lake - silt and clay varves & $\begin{array}{l}\text { - Magnetic domain: in SP }+ \text { SD range but this is due to hematite that was not } \\
\text { fully saturated } \\
\text { - } \chi_{0}-T, H_{C}, H_{\mathrm{CR}} \text {, and } S \text {-ratio: hematite is the dominant magnetic mineral } \\
\text { - Hematite comes from Belt-Purcell Supergroup in the surrounding area } \\
\text { - } K \text { is consistent up-unit } \\
\text { - Grain size (mean }=2.5 \mu \mathrm{m} \text { ) is consistent up-unit }\end{array}$ \\
\hline \multirow[t]{3}{*}{$\begin{array}{l}\text { Glacial Lake Columbia } \\
\text { (Manila Creek) }\end{array}$} & $\nabla$ Flood - bedded and rippled sand, silt and clay & $\begin{array}{l}\text { - Magnetic domain: PSD trending toward MD } \\
\text { - } \chi_{0}-T \text { : titano-magnetite is the dominant magnetic mineral } \\
\text { - Titano-magnetite was eroded from the Idaho Batholith and sediment in eastern } \\
\text { glacial Lake Columbia by the floodwaters } \\
\text { - } K \text { decreases up unit } \\
\text { - Grain size (mean }=27.3 \mu \mathrm{m} \text { ) decreases up-unit }\end{array}$ \\
\hline & $\begin{array}{l}\nabla \text { Transition to glaciolacustrine sediment - laminated or } \\
\text { massive silt and clay }\end{array}$ & $\begin{array}{l}\text { - Grain size decreases gradually but } K, J_{\mathrm{S}}, J_{\mathrm{RS}} \text {, and } S \text {-ratio increase abruptly from } \\
\text { flood to glaciolacustrine sediments } \\
\text { - S-ratio shows that a higher-coercivity mineral (hematite) is present at the top } \\
\text { of each flood unit } \\
\text { - Hematite is dominant in the fine-grained sediment deposited as fine grains } \\
\text { settle out of the water column after the high-energy floodwaters have passed } \\
\text { - Glacial Lake Missoula is the only possible source of this hematite }\end{array}$ \\
\hline & $\Delta$ Deepened lake - laminated silt and clay & $\begin{array}{l}\text { - Magnetic domain: PSD } \\
\text { - } \chi_{0}-T \text { : magnetite is the dominant magnetite mineral } \\
\text { - Magnetite sourced from volcanics north of site } \\
\text { - } K \text { is consistent up-unit } \\
\text { - Grain size (mean }=4.2 \mu \mathrm{m} \text { ) is consistent up-unit }\end{array}$ \\
\hline
\end{tabular}

a Symbols relate to Figures 4-7.

expected in sediment characterized by ripples and soft-sediment deformation structures, which are indicative of very rapid sedimentation.

At Manila Creek, there are clear transitions in depositional environments resulting from the repeated influx of floodwaters to the site. Grain size, for example, markedly increases at contacts between glaciolacustrine sediments and overlying flood sediments as do the ratios $J_{\mathrm{RS}} / J_{\mathrm{S}}$ and $H_{\mathrm{CR}} / H_{\mathrm{C}}$ (Fig. 5). On the other hand, changes in some magnetic properties are not as evident at this contact; the small changes in $Q, J_{\mathrm{S}}, J_{\mathrm{RS}}, H_{\mathrm{C}}, H_{\mathrm{CR}}$ reflect the fact that the glaciolacustrine sediment is dominated by magnetite and the flood sediment is dominated

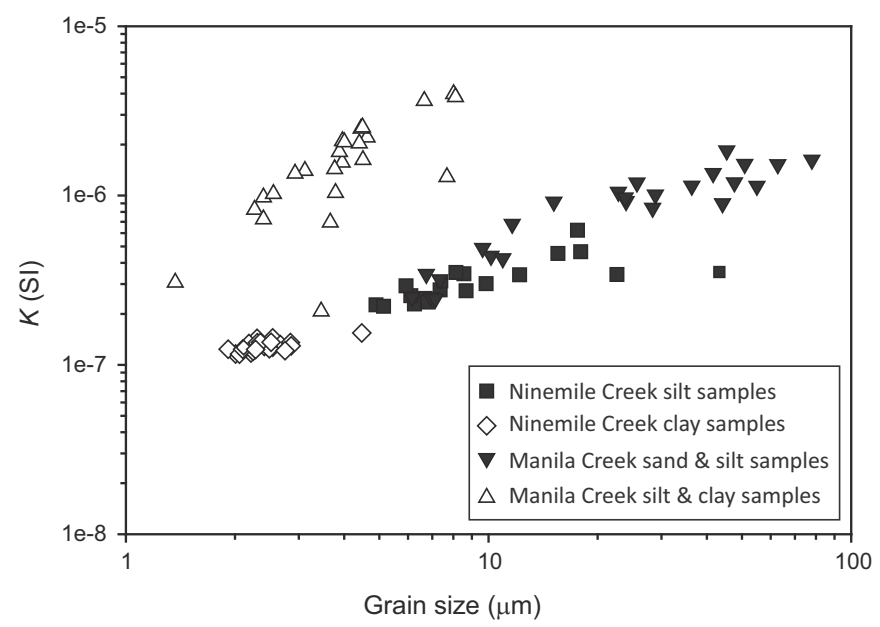

Figure 7. Plot of grain size vs. volumetric magnetic susceptibility $(K)$. The linear trends indicate that the concentration of magnetite is directly proportional to grain size for each sediment type. by titano-magnetite. In contrast, many of the magnetic properties (e.g., NRM, $K, J_{\mathrm{S}}, J_{\mathrm{RS}}$, and $S$-ratio) change abruptly across the gradational sediment boundaries marking the ends of floods and resumption of normal glaciolacustrine sedimentation. This change is discussed in more detail below.

Magnetic susceptibility is strongly related to sediment grain size at each site and within each depositional environment (Figs. 4 and 5). Figure 7 shows that the two properties vary almost proportionally, indicating that the process that transported the larger grain sizes also transported more of the denser magnetite grains. Each of the four groups displays its own proportional relationship, but there is no common relation between magnetic susceptibility and grain size at all sites. This result indicates that proportions of ferromagnetic minerals differ among the four groups, probably because of differences in sediment provenance.

Similarly, the distributions of $J_{\mathrm{RS}} / J_{\mathrm{S}}$ and $H_{\mathrm{CR}} / H_{\mathrm{C}}$ (Fig. 6) indicate that trends in magnetic domain state and grain size are similar within each lithologic unit but distinct between units (Figs. 4-6), again highlighting the different sedimentary environments. Samples from each lithologic unit display homogeneity and most tend to cluster along a hyperbola, except for the Ninemile Creek clay samples. There is a clear separation of the two lithologies at Ninemile Creek and only a small amount of overlap of the flood and glaciolacustrine samples at Manila Creek. The overlap in the latter case may be explained by the gradual change from the flood environment to the glaciolacustrine environment. The upper three samples in each flood unit from Manila Creek are highlighted in Fig. 6. The three samples from the lower flood unit clearly overlap with the glaciolacustrine samples. Glacial Lake Missoula flood (sand and silt) samples at Manila Creek plot on a hyperbola slightly above and to the right of Manila Creek glaciolacustrine (silt and clay) samples, probably due to a higher proportion of hematite. Flood samples at Manila Creek plot toward the bottom right of the graph, indicating 
that they contain the largest magnetic grains, probably in the MD range, a conclusion supported by the low $H_{\mathrm{C}}$ values (9-16 $\mathrm{mT}$ ).

Median grain size increases in each lithologic unit downward and to the right in the graph, consistent with the magnetic domain state. The largest magnetic grains are found in the lower flood unit at Manila Creek. The uppermost three samples from the lower flood unit (arrows in Fig. 6) have the smallest magnetic domains and grain sizes of the entire unit. The uppermost samples from the upper flood unit have the smallest grain sizes but not the smallest magnetic domains. It is possible that unsaturated hematite is underestimating both $H_{\mathrm{C}}$ and $H_{\mathrm{CR}}$ and also producing even lower $H_{\mathrm{C}}$ values than expected. Comparison of magnetic domains among sites is not entirely consistent with grain size. Thus, magnetic hysteresis ratios can be used as a proxy for grain size at a site, but the relationship between sites is more complicated if different magnetic minerals are involved.

\section{Sediment provenance}

The high-temperature susceptibility data (Table 1) highlight the difference in magnetic mineralogy between the varved clay deposits at Ninemile Creek (hematite) and the glacial Lake Missoula flood and glaciolacustrine deposits at Manila Creek (magnetite and titanomagnetite). Higher values of $H_{\mathrm{C}}$ and $H_{\mathrm{CR}}$ and lower values of $J_{\mathrm{R}}$ and $J_{\mathrm{RS}}$, which characterize glacial Lake Missoula varved clay sediment, are consistent with the presence of hematite. Lower values of $H_{\mathrm{C}}$ and $H_{\mathrm{CR}}$ and higher values of $J_{R}$ and $J_{R S}$ confirm the presence of magnetite or titano-magnetite in both glacial Lake Columbia sediment and glacial Lake Missoula flood deposits.

The hematite at Ninemile Creek is derived from the mid-Proterozoic Belt-Purcell Supergroup, which is widespread in the glacial Lake Missoula basin (Fig. 1; Elston et al., 2002; Vuke et al., 2007). Rivers flowing into glacial Lake Missoula from the south, southeast, and east supplied sediment to the Ninemile Creek site; this bedrock is dominated by the hematite-bearing Upper and Lower Missoula, Piegan, and Ravalli groups (Elston et al., 2002). Titano-magnetite in the lower part of the glaciolacustrine (silt) units at Ninemile Creek might also have sources in the Belt-Purcell Supergroup, but it could also have been derived from monzonite and granodiorite of the Idaho Batholith south of the site (Fig. 1; Lewis et al., 2012). Titano-magnetite was only deposited at Ninemile Creek early during glacial Lake Missoula filling cycles when sediment was derived from sources close to the site. Silt at Ninemile Creek likely contains hematite as well (as indicated by the low $S$-ratios around 0.98 ), but its weak susceptibility is masked by the stronger contributions of titano-magnetite. Once the lake deepened, the site was distant from any sediment input from the south and titano-magnetite was no longer deposited in significant amounts.

Magnetite in glacial Lake Columbia sediments at Manila Creek is likely derived locally from Eocene dacite flows (Sanpoil Volcanics) and monzodiorite (Devils Elbow suite), both of which crop out north of the study site (Fig. 1; Stoffel, 1990). Eocene, Cretaceous, and Jurassic intrusive rocks farther north in British Columbia might also have provided magnetite to western glacial Lake Columbia (Laberge and Pattison, 2007).

\section{Provenance of flood sediment}

Jumps in NRM, $K, J_{\mathrm{S}}, J_{\mathrm{RS}}$, and the $S$-ratio at Manila Creek (Fig. 5) indicate that sediment deposition in glacial Lake Columbia changed in character at the end of each flood event when the lake transitioned back to a normal glaciolacustrine environment. This change is not discernable from grain size alone $\left(D_{50}\right.$; Fig. 6$)$, which indicates a general decrease in particle size throughout the flood unit and a gradual transition into glaciolacustrine deposition. The $S$-ratio proved to be the most useful parameter for elucidating what occurred as the flood sediments were deposited; it also helped explain similar trends in the other magnetic parameters.

The low S-ratio reflects the presence of high-coercivity magnetic minerals, such as hematite, and displays a consistent, repetitive pattern through the strata at Manila Creek (Fig. 5). We attribute the consistent decrease in $S$-ratio values at the end of a flood to deposition of finegrained hematite derived from glacial Lake Missoula. There is no major local source that could provide a large amount of hematite to the Manila Creek site. Samples that display this hematite signal were collected from the upper part of flood units, which are fine-grained, commonly massive, and can have a pinkish tinge, similar to glacial Lake Missoula sediments (2.5 YR 7/1; reddish gray; Fig. 8). This fine-
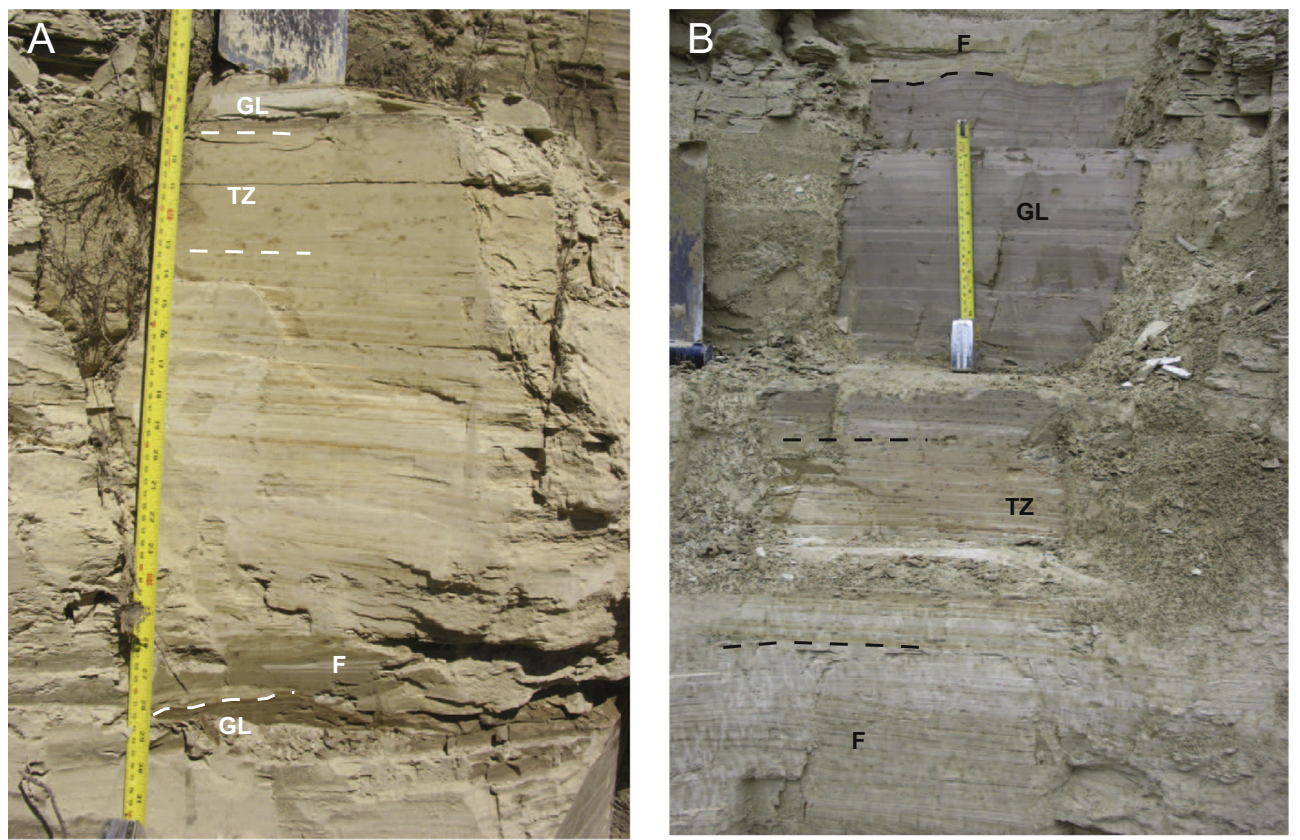

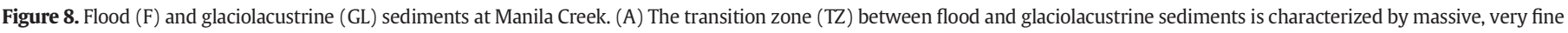

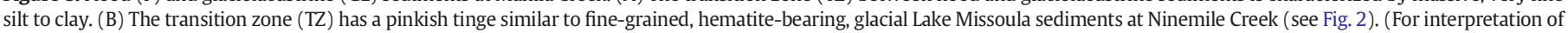
the references to color in this figure, the reader is referred to the web version of this article.) 
grained sediment likely settled out of the water column in the months after the high-velocity currents of the flood had abated. ${ }^{3}$ This signal is only present at the end of floods, indicating that the hematite is focussed in the finer-grained sediment. Glacial Lake Missoula floodwaters traveled $\sim 240 \mathrm{~km}$ from the ice dam to the Manila Creek site. They would have carried fine-grained, hematite-rich silt and clay eroded from the floor of glacial Lake Missoula.

Floodwaters would also have eroded and transported glacially deposited sediment from beneath the Purcell Trench lobe and glaciolacustrine sediment from eastern glacial Lake Columbia. Purcell Trench lobe deposits and some of the sediment in eastern glacial Lake Columbia would have been locally derived from granodiorite and tonalite of the Idaho Batholith (Fig. 1) and contained titano-magnetite. These more proximally derived sediments characterize the coarser flood sediments deposited in the lower part of the flood units at Manila Creek, which are dominated by titano-magnetite. If hematite is present in these coarser sediments, it is overwhelmed by magnetite and titano-magnetite, which have $K$ values at least one order of magnitude larger than those of hematite.

This model of deposition helps to explain similar trends in other magnetic parameters at Manila Creek. A decrease in $K$ at Manila Creek thus does not strictly represent a decrease in grain size over the course of the flood, but rather reflects the relative concentrations of hematite and magnetite. $K$ is thus more strongly controlled by the concentration of ferromagnetic minerals than grain size. This fact highlights that there are distinct sedimentary sources for the flood and glaciolacustrine sediments. Magnetic susceptibility values change little across the erosional boundary at the beginning of a flood because larger magnetic grains of titano-magnetite eroded en route were deposited at that time. $J_{S}$ and $J_{\mathrm{RS}}$, which are both measures of magnetic mineral concentration, have nearly identical trends to $K$; both decrease with the increasing relative concentrations of hematite. $H_{C}$ and $H_{\mathrm{CR}}$ in the lower flood unit are generally mirror images of $K, J_{\mathrm{S}}$, and $J_{\mathrm{RS}}$, increasing upward through the unit with the increasing influence of the higher coercivity hematite. In contrast, the rock magnetic record of the second flood unit does not show a simple pattern. Fluctuations in $\mathrm{D}_{50}, K, Q J_{\mathrm{S}}, H_{\mathrm{C}}, H_{\mathrm{CR}}$, and the $S$-ratio around the fifth sample from the bottom likely indicate current fluctuations during the flood with an increase in grain size and coarse titanomagnetite grains. The highest values of $H_{\mathrm{C}}$ and $H_{\mathrm{CR}}$ are not coincident with the lowest values of the $S$-ratio at the top of the unit. Instead, the $H_{\mathrm{C}}$ and $H_{\mathrm{CR}}$ values of the top five samples are lower than expected from the $S$-ratio. This variability in $H_{\mathrm{C}}$ and $H_{\mathrm{CR}}$ may indicate a larger effect of current fluctuations during the flood.

Although this study focuses on only two units at Manila Creek, the two units are representative of the majority of the 46 units studied at the site. Figure 9 shows NRM, $K$ and $Q$ values for the lowest 25 flood units. The sample spacing is larger, but most units show similar patterns to those documented in the detailed study of the two units: relatively gradual changes across the erosional boundary at the base of the flood sediment and sharp changes at the gradational boundary between the flood sediment and the glaciolacustrine sediment above. This pattern is not evident in the upper 21 flood units because the sampling resolution is too coarse and the uppermost eight flood units are thin $(\sim 5 \mathrm{~cm})$ and do not contain coarser sand and silt grains. There is no indication visually that these late floods had a source other than glacial Lake Missoula, but Gaylord et al. (2007) ascribe some of the stratigraphically higher flood beds (not specifically identified) to meltwater from a retreating Cordilleran ice sheet on the basis of detrital zircon geochronology. Thus, with the possible exception of a few units near the top of the exposure, a similar process of deposition likely affected most of

\footnotetext{
${ }^{3}$ It would have taken between 8 and 22 months for the fine particles in the water column to settle to the lake floor at Manila Creek, assuming that the surface of glacial Lake Columbia was $715 \mathrm{~m}$ above sea level (asl) at its highest stand, that the lake floor was between 457 and $502 \mathrm{~m}$ asl at Manila Creek (Atwater, 1986), and that fine-grained siltto clay-size particles $(4.5 \mu \mathrm{m}-3 \mu \mathrm{m})$ settle at a rate of $0.27-0.62 \mathrm{~mm} / \mathrm{min}$.
}
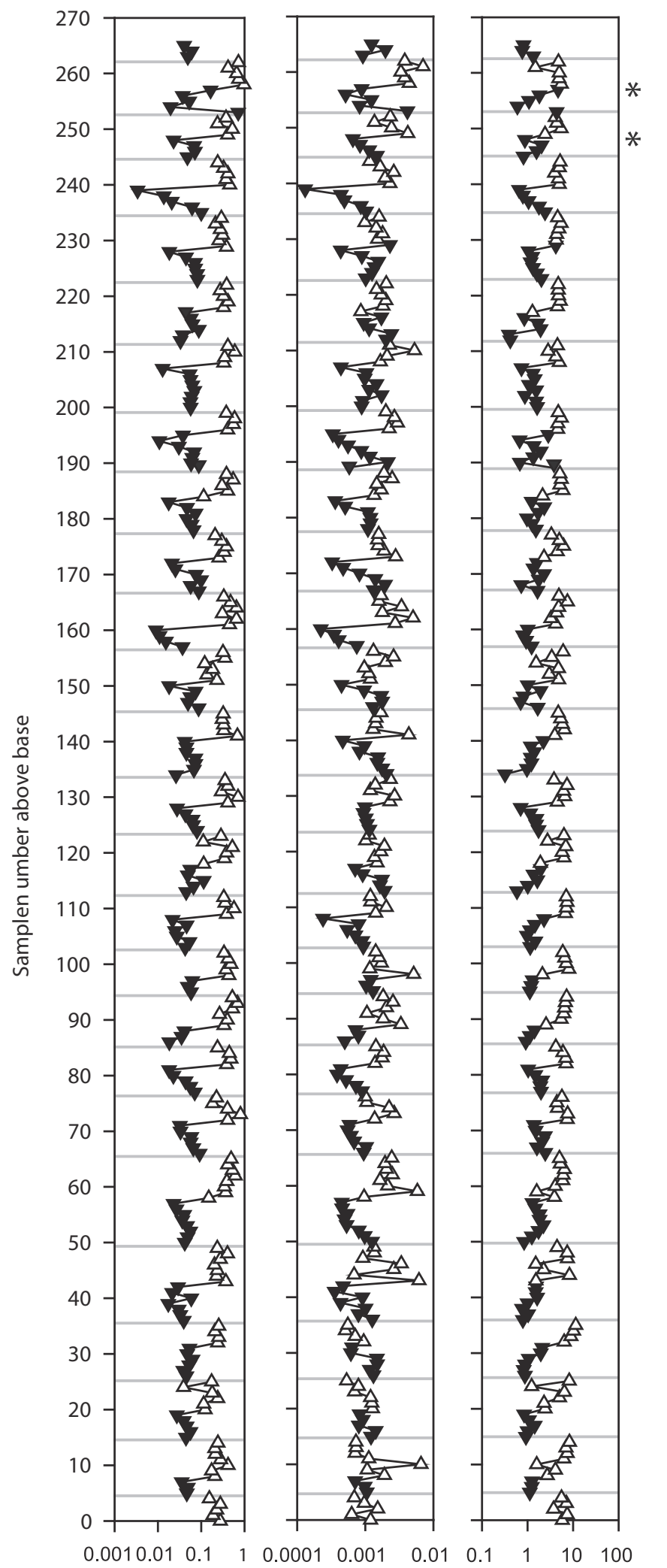

$\operatorname{NRM}(A / m)$

$K(\mathrm{SI})$

Figure 9. NRM, $K$, and $Q$ for the lowest 25 units at Manila Creek. Glaciolacustrine samples are open triangles; flood samples are closed, upside-down triangles. Horizontal lines delineate the base of flood units. Note the gradual decrease in both NRM and $K$ across erosional contacts at the base of the flood units and the sudden increase in NRM and $K$ in the transition from flood units to glaciolacustrine units. The asterisks denote the two units in Fig. 6, although the samples represented here are from a different dataset that is not as detailed. 
the flood units at Manila Creek, involving sedimentation of fine-grained glacial Lake Missoula hematite at the end of each flood.

\section{Conclusion}

High-resolution rock magnetic analysis of last glacial (Marine Oxygen Isotope Stage 2), fine-grained glaciolacustrine and glacial outburst flood sediment deposited in glacial Lake Missoula and glacial Lake Columbia highlights differences in depositional processes and sediment provenance. In particular, this study shows that these techniques can be successfully used on fine-grained sediments deposited by higher-energy processes, such as glacial outburst flooding and turbidity currents.

The origin of Marine Oxygen Isotope Stage 2 flood deposits in northern and central Washington has long been debated. At the Manila Creek site, lower $S$-ratio, magnetic susceptibility $(K)$, saturation magnetization $\left(J_{S}\right)$, and saturation remanence $\left(J_{R S}\right)$ indicate the presence of a highercoercivity magnetic mineral (hematite) in the finest-grained sediment deposited at the end of each flood. There is no local source of hematite near the Manila Creek site, but thermomagnetic susceptibility measurements $\left(\chi_{0}-T\right)$ indicate the presence of hematite in fine-grained glacial Lake Missoula varved sediment, leading to the conclusion that flood beds at Manila Creek were deposited by glacial Lake Missoula outburst floods.

Supplementary data to this article can be found online at http://dx. doi.org/10.1016/j.yqres.2014.09.005.

\section{Acknowledgments}

This research was supported by the Natural Sciences and Engineering Research Council of Canada (NSERC) through Discovery Grants to Clague (24595) and Barendregt (0581), and an NSERC PGS B Scholarship to Hanson. J. Dykstra and K. Wilkie assisted with fieldwork, and C. Brown assisted with grain-size analysis. J. Baker provided laboratory supervision and assistance. K. Adams and two anonymous reviewers provided thoughtful and critical reviews that greatly improved this paper.

\section{References}

Allison, I.S., 1978. Late Pleistocene sediments and floods in the Willamette Valley. The Ore Bin 40, 177-191 (and 193-202).

Atwater, B.F., 1984. Periodic floods from glacial Lake Missoula into the Sanpoil Arm of glacial Lake Columbia, northeastern Washington. Geology 12, 464-467.

Atwater, B.F., 1986. Pleistocene glacial lake deposits of the Sanpoil River Valley, northeastern Washington. U.S. Geological Survey Bulletin 1661.

Atwater, B.F., 1987. Status of glacial Lake Columbia during the last floods from glacial Lake Missoula. Quaternary Research 27, 182-201.

Baker, V.R., 1973. Paleohydrology and sedimentology of Lake Missoula Flooding in Eastern Washington. Geological Society of America Special Paper 144.

Baker, V.R., 1978. Quaternary geology of the Channeled Scabland and adjacent areas. In: Baker, V.R., Nummedal, D. (Eds.), The Channeled Scabland: A Guide to the Geomorphology of the Columbia Basin, Washington. National Aeronautics and Space Administration, Washington, DC, pp. 17-36

Baker, V.R., Bunker, R.C., 1985. Cataclysmic late Pleistocene flooding from glacial Lake Missoula: a review. Quaternary Science Reviews 4, 1-41.

Bjornstad, B.N., 1980. Sedimentology and Depositional Environment of the Touchet Beds, Walla Walla River Basin, WashingtonM.Sc. thesis Eastern Washington University, Cheney, WA.

Blanchet, C.L., Thouveny, N., Vidal, L, Leduc, G., Tachikawa, K., Bard, E., Beaufort, L., 2007. Terrigenous input response to glacial/interglacial climatic variations over southern Baja California: a rock magnetic approach. Quaternary Science Reviews 26, 3118-3133.

Bretz, JH., 1925. The Spokane flood beyond the Channeled Scablands. Journal of Geology 33, 97-115 (and 236-259).

Bretz, JH., 1928. Bars of the Channeled Scabland. Geological Society of America Bulletin 39 643-701.

Bretz, JH., 1932. The Channeled Scabland. International Geological Congress Guidebook 22: Excursion C-2.

Bretz, JH., 1969. The Lake Missoula floods and the Channeled Scabland. Journal of Geology 77, 505-543.

Bretz, JH., Smith, H.T.U., Neff, G.E., 1956. Channeled Scabland of Washington: new data and interpretations. Geological Society of America Bulletin 67, 957-1049.

Bunker, R.C., 1982. Evidence of multiple Late-Wisconsin floods from glacial Lake Missoula in Badger Creek, Washington. Quaternary Research 18, 17-31.
Carson, R.J., McKhann, C.F., Pizey, M.H., 1978. The Touchet beds of the Walla Walla Valley. In: Baker, V.R., Nummedal, D. (Eds.), The Channeled Scabland: A Guide to the Geomorphology of the Columbia Basin, Washington. National Aeronautics and Space Administration, Washington, DC, pp. 173-178.

Carter-Stiglitz, B., Valet, J.-P., LeGoff, M., 2006. Constraints on the acquisition of remanent magnetization in fine-grained sediments imposed by redeposition experiments. Earth and Planetary Science Letters 245, 427-437.

Chambers, R.L., 1971. Sedimentation in Glacial Lake MissoulaM.Sc. thesis University of Montana, Missoula, MT.

Chambers, R.L., 1984. Sedimentary evidence for multiple glacial lakes Missoula. In: McBane, J.D., Garrison, P.B. (Eds.), Northwest Montana and Adjacent Canada. Montana Geological Society, Billings, MT, pp. 189-199.

Clague, J.J., Armstrong, J.E., Mathews, W.H., 1980. Advance of the late Wisconsinan Cordilleran ice sheet in southern British Columbia since 22,000 yr BP. Quaternary Research $13,322-326$.

Clague, J.J., Barendregt, R., Enkin, R.J., Foit Jr., F.F., 2003. Paleomagnetic and tephra evidence for tens of Missoula floods in southern Washington. Geology 31, 247-250.

Craig, R.G., 1987. Dynamics of a Missoula flood. In: Mayer, L., Nash, D. (Eds.), Catastrophic Flooding. Allen and Unwin, London, pp. 302-332.

Day, R., Fuller, M., Schmidt, V.A., 1977. Hysteresis properties of titanomagnetites: grain size and composition dependence. Physics of the Earth and Planetary Interiors 13, 260-267.

Denlinger, R.P., O'Connell, D.R.H., 2010. Simulations of cataclysmic outburst floods from Pleistocene glacial Lake Missoula. Geological Society of America Bulletin 122, 678-689.

Dunlop, D.J., 2002a. Theory and application of the Day plot $\left(M_{r s} / M_{\mathrm{s}}\right.$ versus $\left.H_{c r} / H_{c}\right)$. 1. Theoretical curves and tests using titanomagnetite data. Journal of Geophysical Research 107. http://dx.doi.org/10.1029/2001JB000486.

Dunlop, D.J., 2002b. Theory and application of the Day plot $\left(M_{r s} / M_{s}\right.$ vs $\left.H_{c r} / H_{c}\right)$. 2. Application to data for rocks, sediments, and soils. Journal of Geophysical Research 107. http://dx.doi.org/10.1029/2001/JB000487.

Dunlop, D.J., Özdemir, Ö., 1997. Rock Magnetism: Fundamentals and Frontiers. Cambridge University Press, Cambridge.

Elston, D.P., Enkin, R.J., Baker, J., Kisilevsky, D.K., 2002. Tightening the belt: paleomagneticstratigraphic constraints on deposition, correlation, and deformation of the Middle Proterozoic (ca. 1.4 Ga) Belt-Purcell Supergroup, United States and Canada. Geological Society of America Bulletin 114, 619-638.

Enkin, R.J., Baker, J., Nourgaliev, D., Iassonov, P., Hamilton, T.S., 2007. Magnetic hysteresis parameters and Day plot analysis to characterize diagenetic alteration in gas hydration-bearing sediments. Journal of Geophysical Research 112, B06S90. http:// dx.doi.org/10.1029/2006JB004638.

Gaylord, D.R., Vervoort, J.D., Pope, M.C., Abplanalp, J.M., Cook, G.W., Dalman, K.A., 2005. Sedimentary analysis and detrital zircon geochronology of late Wisconsin glacial outburst flood deposits, western Montana and eastern Washington. Geological Society of America Abstracts with Programs 37, 430.

Gaylord, D.R., Pope, M.C., Cabbage, P.R., Glover III, J.F., Anfinson, O.A., Baar, E.E., Vervoort, J.D., 2007. Provenance of glacial outburst flood deposits in the Channeled Scabland, WA; influence of glacial Lake Missoula, meltwater, Snake River, and Bonneville flood sources. Geological Society of America Abstracts with Programs 39, 82.

Hanson, M.A., 2013. Sedimentological and Paleomagnetic Study of Glacial Lake Missoula Lacustrine and Flood SedimentPh.D thesis Simon Fraser University, Burnaby, BC.

Hanson, M.A., Lian, O.B., Clague, J.J., 2012. The sequence and timing of large late Pleistocene floods from glacial Lake Missoula. Quaternary Science Reviews 31, 67-81.

Hao, Q., Oldfield, F., Bloemendal, J., Guo, Z., 2008. Particle size separation and evidence for pedogenesis in samples from the Chinese Loess Plateau spanning the past 22 m.y. Geology 36, 727-730.

Hrouda, F., 2003. Indices for numerical characterization of the alternation processes of magnetic minerals taking place during investigation of temperature variation of magnetic susceptibility. Studia Geophysica et Geodaetica 47, 847-861.

Hrouda, F., Chlupáčová, M., Novák, J.K., 2002. Variations in magnetic anisotropy and opaque mineralogy along a kilometre deep profile within a vertical dyke of the syenogranite porphyry at Cínovec (Czech Republic). Journal of Volcanology and Geothermal Research 113, 37-47.

Hrouda, F., Mueller, P., Hanak, J., 2003. Repeated progressive heating in susceptibility vs. temperature investigation; a new palaeotemperature indicator? Physics and Chemistry of the Earth 28, 653-657.

Kietzman, D.R., 1985. Paleomagnetic Survey of the Touchet Beds in Burlingame Canyon of Southeast WashingtonM.Sc. thesis Eastern Washington University, Cheney, WA.

Kuehn, S.C., Froese, D.G., Carrara, P.E., Foit Jr., F.F., Pearce, N.J.G., Rotheisler, P., 2009. Majorand trace-element characterization, expanded distribution, and a new chronology for the latest Pleistocene Glacier Peak tephras in western North America. Quaternary Research 71, 201-216.

Laberge, J.D., Pattison, D.R.M., 2007. Geology of the western margin of the Grand Forks complex, southern British Columbia: high-grade Cretaceous metamorphism followed by early Tertiary extension on the Granby fault. Canadian Journal of Earth Sciences 44, 199-228.

Lattard, D., Engelmann, R., Kontny, A., Sauerzapf, U., 2006. Curie temperatures of synthetic titanomagnetites in the Fe-Ti-O system: effects of composition, crystal chemistry, and thermomagnetic methods. Journal of Geophysical Research 11, B12S28. http:// dx.doi.org/10.1029/2006JB004591.

Lesemann, J.-E., Brennand, T.A., 2009. Jökulhlaups from the southern margin for the Cordilleran ice sheet. Geological Society of America Abstracts with Programs 41, 169

Levish, D.R, 1997. Late Pleistocene Sedimentation in Glacial Lake Missoula and Revised Glacial History of the Flathead Lobe of the Cordilleran Ice Sheet, Mission Valley, MontanaPh.D. thesis University of Colorado, Boulder, CO.

Lewis, R.S., Link, P.K., Stanford, L.R., Long, S.P., 2012. Geologic Map of Idaho. Idaho Geological Survey M-9. 
Lovett, C.K., 1984. Paleomagnetism of the Touchet Beds of the Walla Walla River Valley, Southeastern WashingtonM.Sc. thesis Eastern Washington University, Cheney, WA.

Maher, B.A., Thompson, R., 1999. Quaternary Climates, Environments and Magnetism. Cambridge University Press, Cambridge.

O'Connor, J.E., Baker, V.R., 1992. Magnitudes and implications of peak discharges from glacial Lake Missoula. Geological Society of America Bulletin 104, 267-279.

O'Connor, J.E., Sarna-Wojcicki, A., Wozniak, K.C., Polette, D.J., Fleck, R.J., 2001. Origin, extent, and thickness of quaternary geologic units in the Willamette Valley, Oregon. U.S. Geological Survey Professional Paper 1620.

Opdyke, N.D., Channell, J.E.T., 1996. Magnetic Stratigraphy. Academic Press, San Diego, CA.

Pardee, J.T., 1910. The glacial Lake Missoula, Montana. Journal of Geology 18, 376-386.

Pardee, J.T., 1942. Unusual currents in glacial Lake Missoula, Montana. Geological Society of America Bulletin 53, 1570-1599.

Patton, P.C., Baker, V.R., Kochel, R.C., 1979. Slack-water deposits: a geomorphic technique for the interpretation of fluvial paleohydrology. In: Rhodes, D.D., Williams, G.P. (Eds.) Adjustments of the Fluvial System. Annual Geomorphology Symposia Series 10, pp. 225-253 (Binghamton, NY).

Shaw, J., Munro-Stasiuk, M., Sawyer, B., Beaney, C., Lesemann, J.-E., Musacchio, A., Rains, B. Young, R.R., 1999. The Channeled Scabland: back to Bretz? Geology 27, 605-608.

Smith, G.A., 1993. Missoula flood dynamics and magnitudes inferred from sedimentology of slack-water deposits on the Columbia Plateau. Geological Society of America Bulletin 195, 77-100.

Smith, L.N., 2006. Stratigraphic evidence for multiple drainings of glacial Lake Missoula along the Clark Fork River, Montana, USA. Quaternary Research 66, 311-322.

Sperazza, M., Moore, J.N., Hendrix, M.S., 2004. High-resolution particle size analysis of naturally occurring very fine-grained sediment through laser diffractometry. Journal of Sedimentary Research 74, 736-743.

Stacey, F.D., Banerjee, S.K., 1974. The Physical Principles of Rock Magnetism. Elsevier, Amsterdam.
Steele, W.K., 1991. Paleomagnetic evidence for repeated glacial Lake Missoula floods from sediments of the Sanpoil River Valley, northeastern Washington. Quaternary Research 35, 197-207.

Stober, J.C., Thompson, R., 1979. An investigation into the source of magnetic minerals in some Finnish lake sediments. Earth and Planetary Science Letters 45, 464-474.

Stoffel, K.L., 1990. Geologic Map of the Republic 1:100,000 Quadrangle 6, Washington. Washington Division of Geology and Earth Resources Open File Report 90-10.

Vuke, S.M., Porter, K.W., Lonn, J.D., Lopez, D.A., 2007. Geologic Map of Montana. Montana Bureau of Mines and Geology Geologic Map 62A, 73 p., 2 sheets, scale 1:500,000.

Waitt, R.B., 1980. About forty last-glacial Lake Missoula jökulhlaups through southern Washington. Journal of Geology 88, 653-679.

Waitt, R.B., 1984. Periodic jökulhlaups from Pleistocene glacial Lake Missoula: new evidence from varved sediments in northern Idaho and Washington. Quaternary Research 22, 46-58.

Waitt, R.B., 1985. Case for periodic, colossal jökulhlaups from Pleistocene glacial Lake Missoula. Geological Society of America Bulletin 96, 1271-1286.

Waitt, R.B., Thorson, R.M., 1983. The Cordilleran ice sheet in Washington, Idaho, and Montana. In: Wright Jr., H.E. (Ed.), Late-Quaternary Environments of the United StatesVolume 1: The Late Pleistocene. University of Minnesota Press, Minneapolis, MN, pp. 53-70.

Waitt, R.B., Denlinger, R.P., O'Connor, J.E., 2009. Many monstrous Missoula floods down Channeled Scabland and Columbia Valley. In: O'Connor, J.E., Dorsey, R.J., Madin, I.P. (Eds.), Volcanoes to Vineyards: Geologic Field Trips through the Dynamic Landscape of the Pacific Northwest: Geological Society of America Field Guide 15, pp. 775-884.

Wentworth, C.K., 1922. A scale of grade and class terms for clastic sediments. Journal of Geology 30, 377-392. 